Article

\title{
Femifesta? A Feminist Manifesto for the 21st Century
}

\author{
Miriam David \\ Education and Policy Studies, Institute of Education, University College London (UCL), \\ London WC1H 0AL, UK; miriam.david@ucl.ac.uk
}

Received: 16 April 2018; Accepted: 30 May 2018; Published: 5 June 2018

\begin{abstract}
I discuss the challenges that feminist activists in academia have raised about how to deal with violence against women and girls (VAWG) and gender-related violence (GRV) through education and training. Whilst VAWG and GRV have been on feminist agendas since the early days of the Women's Liberation Movement (WLM) in the 1960s and 1970s they were rarely linked with key demands for equal educational opportunities. It is still the case that feminist work on VAWG is rarely coupled with feminist studies in mainstream education. Drawing on a European Union (EU) funded study in the Daphne programme III-the GAP-work project-I consider strategies to address questions of VAWG and GRV for children and young people through education. This entailed involving 'youth professionals' and educators in four countries, namely Ireland, Italy, Spain and the UK in training. Drawing on this international educational work, I present an outline of a Feminist Manifesto or a 'femifesta' for education. This brings together feminist demands for policy changes in mainstream education through sex and relationships education to deal with VAWG and GRV, with feminist pedagogies to transform social and sexual or gender relations in schools.
\end{abstract}

Keywords: activism; education; feminism; Gender Based or Related Violence (GBV) (GRV); manifesto; sexual abuse; sexual harassment; Violence Against Women and Girls (VAWG)

\section{Introduction}

Sexual abuse and sexual harassment as forms of violence against women and girls (VAWG) and gender-related violence (GRV) are high on the public and political agendas in both the global north and global south in the second decade of the twenty-first century. Raising these feminist issues constitutes a form of political education about misogyny, patriarchy, sexism or 'toxic masculinity' although there are few educational or legal international solutions. It is welcome that some of the campaigns of feminist activists, over many decades and especially since the beginnings of the Women's Liberation Movement (WLM) in the 1960s and 1970s, have finally come to the fore and are debated in international public arenas.

Nevertheless, the ways that they are addressed in such public and global arenas are chiefly about celebrities or public figures, through social and traditional print media. There is neither critical debate nor practical solutions addressed to the state in more traditional political and public fora. These have been called 'state feminism' (Walby 1986) and more recently 'governance feminism' (Halley 2006). This may be because of the wider political and socio-economic global changes that have occurred over the last fifty years or more. Indeed, it has been argued that the characteristics of feminism have been transformed because of the wider global transformations, moving discussions of women, sexual relations and sexualities to issues of gender. The more that gender is 'mainstreamed', as I argue, this mutes the attention paid to legislation about VAWG and GRV (Walby 2011). Halley (2006) has also provided a critique of 'governance feminism', whilst others more recently have developed the notion of 'carceral feminism' (White 2015) about how some legalistic demands might lead to more state violence against women, especially poor, classed and raced groups. 
Feminism formerly was seen as a collective and socialist political movement for women's equality, women's liberation and women's rights both nationally and internationally. The changes in feminism are seen as part of broader shifts towards neoliberalism from social democracy with a growing emphasis on the personal rather than the political. The once sociological term 'gender' has come to replace that of 'sex' as a way of describing cultural and social relations and divisions, including through the law. Inevitably, this has been a relatively slow process of political transformation, although it has been closely linked with the moves from the notions of women's liberation to forms of feminism, and from second-wave feminism, in particular.

Where these issues of sex, gender and violence are addressed more legalistically or in the political arena in the UK, they are now about the relatively narrow question of gender recognition and identity (through new contested debates about the (Gender Recognition Act 2004) of the UK) or 'the gender pay gap' in forms of employment. Here the latter question is more about how large-scale organisations breach the law by not accounting for gender discrimination in their individual workforces rather than by addressing the larger question of fairness and justice for women and equality with men in education, employment or the wider society.

On the other hand, in the UK there have been moves to replace the very specific Equal Pay Act 1970 and Sex Discrimination Act 1975 (both of which feminists campaigned for) with the broader Equalities Act, 2010. This latter Act was passed under a Labour government, with Harriet Harman-a state socialist-feminist—-taking the lead, as Harman herself argues in her autobiography (Harman 2017). She also shows the difficulties of taking a leadership role as a feminist and woman, even within the Labour party. The everyday sexism or patriarchal attitudes within the Labour party itself remain to be resolved. Their emphasis is what may be considered 'governance feminism'.

In this paper, I address the campaigns of feminist activists in global academia around some specific educational solutions for children and young people. They are on elaborating sex and relationships education as a means to dealing with VAWG and GRV. I base this on a European Union (EU) funded study, through their Daphne programmes, which was specifically about VAWG and training and educational projects (David 2016a). This study to address the issues of the sexual and social relations between boys and girls, men and women or across the genders, was funded for 2 years from 2013-2015. The GAP-work project took place in four countries of the EU, namely Ireland, Italy, Spain and the UK.

We set first the broad legal and international context of women's changing position over the course of the previous several decades, addressing differences as well as similarities in this across the four countries. Second, we undertook pilot local 'actions' to educate or train 'youth professionals' to challenge VAWG or GRV in various educational settings for children and young people. How we found the youth professionals varied depending upon local circumstances: some were in higher education on professional education courses, others were youth or social workers or teachers, and others were in medical or health settings.

Drawing on these studies, I developed a manifesto to address VAWG or GRV through schools and higher education (David 2016a). This 'femifesta', to borrow a term also discussed by Anna Hickey-Moody (2016), is specifically educational or pedagogic (David 2017). It could lead to transformative change around VAWG or GRV and the general questions of how to deal with gender and/or sexualities through embedding such strategies in schools and higher education. It could make men and women alike responsible for the transformative changes necessary to avoid the endless cycle of misogyny and VAWG and reclaim (socialist) feminism (David 2016b).

\section{Feminist Activism and Campaigning: The Background}

As the title of this special issue indicates, the question of what is feminism? is complex and often intertwined with generational issues as well as academic and socio-political analysis and developments. I have been involved in feminist activism and academia for about 50 years, committed as I am to the values of social justice, human and civil rights and fairness for women linked with socio-political change (David 2016b). My strategies and tactics have changed over the course of my life, 
inevitably. I have learned a good deal from the various generations of feminists that I have worked and researched with.

In particular, my brand of socialist feminism has been changed by working with younger generations, committed as they are to different ways of looking at gender and feminist identities. I have found myself developing ways of thinking about post-structural feminism, including addressing lesbian, gay, bi-sexual and trans-sexual and queer identities (LGBTQi). In the GAP-work project, we pondered our definitions and, in particular, questioned the international notion of gender-based violence (GBV). This led us to an acceptance of the more broad definition of GRV, as being more inclusive of LGBTQi as an integral part of gender violences (a term that Barbara Biglia, the leader of the Spanish project is committed to) (Alldred and David 2015). This is to illustrate what so-called 'carceral feminism' addresses, namely the potential violence against women from the state and its agents itself. In other words, feminist calls for the incarceration of violent men may lead to worse abuses and violence than hitherto.

It is necessary, however, to look briefly at the ways in which feminism in academic research in relation to women's activism has developed over the preceding generations. If we look backwards we find some extraordinary stories of women's resilience in the teeth of violent opposition or abuse and harassment. These date back over many centuries, for example, to a time when women were abused and killed for being witches (Ehrenreich and English 1973). Wollstonecraft (1972) in her A Vindication of the Rights of Women published in Britain in 1972 (and republished in argued most strongly for women's equality, given the strictures on women's lives compared to men's, but did not use the term feminism.

Feminism was a term coined in the nineteenth century to focus on, and campaign for, women's rights and equality and fairness with men within whatever society women found themselves. It is about values and beliefs. Some of the stories, from the nineteenth and early twentieth century, are about political activism and campaigns around women's suffrage and women's rights on a par with men. In one account, that by the sociologist of education, Olive Banks, in Becoming a Feminist: The Social Origins of First Wave Feminism (Banks 1986) these campaigns came to be known as 'first wave feminism', specifically in relation to the UK and USA. Banks writes of 3 generations of feminists in nineteenth century and early twentieth century Britain. She focuses on their education as well as politics.

First wave feminism, in the USA, could be said to have started in the mid-nineteenth century, with a huge rally for women's rights in Seneca Falls in 1848 by contrast with the UK (David 2016a, p. 72). However, the campaign for women's suffrage, in the USA, like in the UK and most other countries was a long and arduous process over many decades, and well into the twentieth century. This is also exemplified by the struggles within the countries of the United Nations, an organisation set up at the end of the Second World War, aiming to establish a framework for civil, human and social rights, including women's. I have argued that 'there has been a secular trend towards transforming women's 'political' lives and international women's rights over the last 150 years' (David 2016a, pp. 61-62).

The WLM or the women's movement from the 1960s has often become known as 'second wave feminism' to contrast it with the earlier political campaigns. This is also contentious and often has derived from the ways feminism developed in the USA. There, the women's movement was said to have started in the 1960s, with the founding of the National Organisation of Women (NOW) followed by a myriad of other social and political activities across the USA. These ideas and those in other countries of Europe started to infuse political campaigns for human and civil rights, which slowly began to include women's rights.

As I showed in Feminism, Gender and Universities: Politics, Passion and Pedagogies (David 2014) the questions of waves can be related not only to the ocean or sea, but to the air, hair or hand. Hewitt (2010) in her edited collection entitled No Permanent Waves: Recasting the Histories of US Feminism claims that 'the concept of waves surging and receding cannot fully capture these multiple and overlapping movements, chronologies, issues and sites' (David 2014, p. 59).

I interviewed over 100 international feminist activists and academics. Whilst I tried to distinguish feminist sensibilities across the generations from first to second to third and possibly fourth wave, 
these classifications or characterisations were heavily contested. For the most part, the feminists I interviewed saw themselves as either second wave or involved in the WLM, or post-structural feminists, moving beyond second wave feminism. They all saw themselves as part of a 'new wave'. In particular, in A Feminist Manifesto for Education I showed how education feminists have been developing new strategies for schools and higher education, in terms of respectful and sensitive education (David 2016a, pp. 89-125). However, the question of whether feminism is the same today as 50 or so years ago remains debatable.

A recent important British book entitled The Stalled Revolution: Is Equality for Women an Impossible Dream? argues that there are two anniversaries to celebrate in 2018 (Tutchell and Edmonds 2018). This book is about what might be summarised as first and second wave feminism, despite the contentiousness of the concepts. One is that of the suffragists and suffragettes who successfully campaigned for 'votes for women', despite the violent reactions of the police and the lawmakers over at least the first decades of the 20th century.

The Representation of the People Act was given Royal Assent on 6th February 1918. The legislation changed the questions of male and female suffrage, and "allowed women to vote in parliamentary elections. Later that year over 8 million women voted for the first time in a General Election ..." (Tutchell and Edmonds 2018, p. 1). It also gave credence to two very different feminist campaigners, namely Millicent Fawcett and Emmeline Pankhurst. Although they came from similar (upper) middle class backgrounds, the strategies they chose for the suffrage campaigns differed. The former was a suffragist, believing in keeping within the law, and the latter a suffragette who believed in whatever methods, including extra-legal actions such as throwing bricks through windows, would achieve their objectives. This meant that many were imprisoned and went on hunger strike so that they were force fed. This was clearly a violent and abusive response to women's rights, what has been called carceral feminism (White 2015).

The second anniversary in 2018 " ... marks fifty years since the great upsurge of feminist feeling that came to be known as the Women's Liberation Movement. The pioneers ... have no statues to record their achievements and, although many of these pioneering women are still alive, they are even less well known than Millicent Fawcett and Emmeline Pankhurst. This is partly the result of modesty. The Women's Liberation Movement was self-consciously egalitarian. It elected no leaders and rejected the cult of personality. But its achievements are all around us" (Tutchell and Edmonds 2018, p. 2).

Tutchell and Edmonds go on to argue that "... the women's movement was the most successful revolution of the twentieth century. Yet it is scarcely celebrated in this country ... The coincidence of the two great anniversaries gives us an opportunity to restore these great victories, and the women who won them, to their proper place in the collective memory of Britain" (Tutchell and Edmonds 2018, p. 3).

This is an important recognition of how second wave feminism had a major impact upon transforming socio-cultural experiences of women from the 1970s onwards, even if political or legal change was more limited. They also argue that

"success was followed by disappointment. In each case the revolution stalled: in the late 1920s as a result of the Great Depression; in the 1980s with rising unemployment following Margaret Thatcher's accession to power. The work of the campaigners was never completed. The question at the heart of this book is whether the time has come for a new liberation campaign and a third leap forward (my emphasis). The need for improvement is very great. Violence against women is common in Britain ..." . (Tutchell and Edmonds 2018, p. 6)

Whether the WLM stalled in the 1980s is what I want to consider here, by looking at international developments around 'gender mainstreaming' and the work of post-structural feminists over GRV. I will return to the contentious argument of this eminently readable book in my conclusion. Tutchell and Edmonds also try to develop a manifesto of sorts but with a focus on new 'demands on the State' in the UK rather than political education or pedagogies. 


\section{International Developments on Feminist Activism}

An important aspect of the GAP-work project on challenging GRV was to understand the broad international socio-political situations of women's rights and VAWG and their necessary political education. We also wanted to comprehend the complex political contexts of the four countries of the EU in which we worked. Two of the countries were examples of Anglophone traditions-Ireland and the UK. Two were examples of Latin countries-Italy and Spain.

Moreover, the project itself came out of the EU's response to the events of 1996 that had shaken Europe and galvanised public and political opinion (David 2016a, p. 36). The discovery of the bodies of a number of missing girls in premises in Belgium in late summer 1996 raised questions about what Europe could do to protect children and women from those who wished to abuse or exploit them for profit. The one-year Daphne Initiative of 1997 struck a chord with non-governmental organisations (NGO) and response was high. As a result, funding was renewed in 1998 and 1999. The Daphne Programme continued the work of the initiative over four years (to 2003), followed by Daphne II (2004-6) and Daphne III (2007-2013) with an average annual budget of 16.7 million euros (David 2016a, p. 36). The Daphne programme continues in the period 2014-2020, as part of the Rights, Equality and Citizenship programme of the EU (but, of course, because of BREXIT, British researchers will no longer be able to apply for funding).

Our GAP-work project was funded under the Daphne III programme which was to provide training and education for professionals. We started by analysing the relevant legal and political frameworks and discourses of the participating countries and their relation to EU legislation. We produced an account of the evolution of the EU's supranational powers and how these relate to each national context. It also describes current legislation on GRV, including gender and sex discrimination (Alldred and David 2015, p. 17; Alldred and Biglia 2015; Biglia et al. 2015).

We argued that there have been at least four 'stages' in the development of gender equality policies, linked with GRV, in the post-war period from 1945. Prior to that, first wave feminists in the global north had successfully campaigned for women's suffrage, and wider socio-cultural changes as we have seen. This process was very uneven, however, across the first half of the twentieth century (David 2016a).

The first period up to the 1970s was one of relative quiescence. With the setting up of the United Nations (UN) in 1945, at the end of the Second World War, there were moves to improve women's rights, although the process remained extremely slow. Of the original fifty-one member states of the UN, only 30 allowed women equal voting rights with them or permitted them to hold public office. Nevertheless, the drafters of the UN charter, including Eleanor Roosevelt-the 'first lady' of the US-deliberately referred to the 'equal rights of men and women' (David 2014, p. 27). No previous international legal document had so forcefully affirmed the equality of all human beings or specifically targeted sex as a basis for discrimination. With the setting up of the UN Commission on Human Rights in the late 1940s, Roosevelt became chair, and later, in the 1960s, she chaired the Kennedy Administration's US Presidential Commission on the Status of Women (David 2016a, p. 43).

During the first 3 decades (1940s-60s), the UN's work on behalf of women focused primarily on the codification of women's legal and civil rights, and the gathering of data on the status of women around the world. It became apparent increasingly that laws, in and of themselves, were not enough to ensure the equal rights of women. There was a tacit commitment, across the EU and other countries of the UN, to the idea of women's rights being part of human or civil rights, although endorsement within the political system was not strong.

The post-war period up to the 1960s and 1970s was marked by progressive and social democratic or at least socially liberal policies, across the global north. It was also a period of relative quiescence as regards feminist activism, although the WLM began to stir, linked to the rise of civil and social rights movements.

The process of change within the EU was linked with change in the UN, moving from women's equality to more nuanced questions. EU legal interventions on gender violence have evolved over 
time as, progressively, EU international treaties have moved the Union's powers from the economic sphere to the social.

Originally, in the 1950s and 1960s, the European Economic Community (EEC) focused upon economic objectives for sexual (rather than gender) equalities. For example, Article 119 of the Treaty of Rome specifically addressed wage parity between men and women. In the 1980s, as a direct result of campaigning by women's groups, the EU developed applied measures (through Directive $76 / 207 /$ EEC), and equal opportunities programmes and a board to introduce positive actions was created (Arribas and Carrasco 2003).

There was an uneven process among the countries of the EU as many only began to join during the 1970s and 1980s, marking their legal convergence with European standards. (As I write we, in the UK, now have less than a year to break that bond and BREXIT). While Italy was a founding member with France and Germany in the early 1950s, the UK and Ireland joined the EU in 1973, and Spain in 1986. During the 1970s, countries both resisted and implemented legislation on equal opportunities and issues of sex discrimination. EU and Italian policies institutionalized some aspects of the feminist movement.

Paradoxically, just as second wave feminists were beginning to find their voice in the political arena with 'demands on the state' (state feminism) for changing policies around equal opportunities (namely equal pay, equal educational opportunities, $24 \mathrm{~h}$ day nurseries, and free contraception and abortion on demand), there was a conservative political backlash against feminist demands from the 1980s onwards.

During the 1970s, 3 further 'demands' were added to the original 4, agreed at Ruskin College, Oxford in 1970. These were legal and financial independence; an end to all discrimination against lesbians and a woman's right to define her own sexuality; and finally but most importantly (from the point of view of this chapter) freedom from intimidation by threat or use of violence or sexual coercion, regardless of marital status, and an end to all laws, assumptions and institutions which perpetuate male dominance and men's aggression towards women. These were added in 1978.

Thus, the second stage was marked by a conservative turn, in the UK and US especially. Other countries of the EU tended to be more ambivalent about the processes. As noted by Tutchell and Edmonds, Margaret Thatcher was the British Conservative Prime Minister and the first woman prime minister in the UK (1979-1990), representing a turn away from social liberalism and democracy (David 2003). Although fiscally conservative, she was not totally opposed to women' rights. Indeed under her administration some women's opportunities in education and employment were opened up, while others closed, particularly for single- or lone parent families. This was similar to the situation in the US while Ronald Regan was president. There were both gains and losses for women's rights across the countries of the EU and indeed the US (David 2016a, p. 64). It is not clear-cut that the revolution stalled.

However, by the early 1990s, the growth of 'global feminism' through the UN and other global organisations had led to more general political acceptance of some demands for social legislation, despite growing fiscal conservatism. This third stage can be characterised by the move towards 'gender mainstreaming' across EU policies and in other countries of the global north, during the 1990s (Walby 2002). Nevertheless, there was strong resistance to such gender mainstreaming from conservative governments in some Anglophone and Latin countries, such as the US, UK, Spain and Italy.

On the other hand, the progressive government in Ireland introduced legal improvements around gender mainstreaming (although not on abortion rights). The expansion of the EU in the 1990s to include countries that championed some gender issues, such as Austria, Finland and Sweden, also resulted in a more gender-sensitive approach to EU policymaking (Hafner-Burton and Pollock 2000). It was not until the 1997 Treaty of Amsterdam that the EU acquired the power to actively intervene in relation to workplace sex/gender discrimination. 
Later, gender mainstreaming, as a policy notion, became more commonplace in the early 21st century across the EU, in response to growing economic and social demands for women's involvement in employment and politics. This stage is characterized by the implementation of gender mainstreaming as policy in progressive governments across the EU.

The institutionalisation of some feminisms and the mainstreaming of their demands (Walby 2002) effected changes in international political rhetoric. Among other things, they led to greater attention being paid to the use of sexist and homophobic language (Millns and Skeet 2013), and they were useful when it came to developing certain gender policies. However, the institutionalization also brought about a co-optation of many feminist claims (Montoya 2009). This is well illustrated by the institutionalization of the very term 'gender'.

On the one hand, the use of the concept made it possible to recognize the socio-cultural norms and values, pressures and incentives involved in constructing gendered subjects and a binary heterosexual order. On the other hand, the term is frequently used to dismiss the necessity of feminist analyses. In fact, it is mostly employed in mainstreaming policies that tend not to be sensitive to central feminist issues in regard to power, hierarchies and difference (Biglia and Olivella-Quintana 2014). In this sense, the feminist revolution may be said to have stalled.

By the second decade of the twenty-first century, the political tendency of most governments across the EU and the global north became that of 'austerity', linked with the global economic crisis, the security paradigm and the rise of Conservative parties in Europe. This is what we consider the fourth stage. With the 2007 Treaty of Lisbon, there was a further expansion of EU powers to include 'security' in its broadest sense. This involved the inclusion of security in policymaking and several EU directives that addressed GRV through a security lens, such as Directive 2011/92/EU of the European Parliament and of the Council of 13 December 2011. This was on combatting the sexual abuse and sexual exploitation of children and child pornography (Alldred and David 2015, p. 18).

The inclusion of gender but not GRV or GBV as a specific focus of EU policymaking meant that tackling gender inequality became one of its most important social objectives. However, achieving gender equality through the EU is problematic as it has limited powers and many are met through the implementation of 'soft' policies. These do not have the legal status of directives but still impact on member states. It remains for individual states to interpret and implement them (Alldred and David 2015, p. 23).

The treaties are binding agreements between EU member countries and are the basic documents whose goals are achieved by regulations and decisions (that are binding), directives (that are set out as goals to be achieved), recommendations and opinions, therefore there are conceptual tensions. In fact, the terminology used in national laws is frequently contradictory, with different expressions for the same form of violence and the same expression for different forms of violence.

We noted that the shift from labour discrimination to risk/security framing of GRV by the EU goes hand-in-hand with the design of national penal GRV legislation that does not include preventative or educational measures in most partner countries, considering GRV as a private rather than a social responsibility. More specifically, GRV is mainly seen as about male perpetrators in adult heterosexual relations. Furthermore, the frequent use of gender-neutral language in laws produces inattention to gendered power relations. Why is it that a commitment to gender equality has not been sufficient to enable tackling questions of GRV or domestic and sexual abuse including child sexual abuse? This was a central theme of our research project especially through education.

\section{The Feminist Activist GAP-Work Project}

I now focus on how we, as education feminists, drew on the scholarship of those of the early second wave feminism, to tackle not only gender equality but also GRV. Despite the impressive array of recent feminist scholarship within the field of gender and education, issues around GRV remain marginalized within the corpus of knowledge. As Alldred and David (2007) noted, this is marginalized in part because of lack of knowledge and understanding of teachers and others about 
how to question gender identities, norms and hetero-normativity. Teacher training rarely takes on board these questions, whether as part of pre-service or in-service education and training, focusing more on the neoliberal agenda of educational achievement. As already seen, we found that teachers and health and youth workers did not feel adequately trained, so we set out to provide some initial training to help to develop this. We wanted to embed more gender consciousness in learning at school and/or university and as part of professional practice.

This feminist activist project combined theoretical and methodological insights from the second wave with the third wave or post-structuralism. We started from the position of problematizing the gender binary, as gender normativities can be seen to reflect the broader deconstructive move of third wave or post-structural feminism and queer theory in particular. Butler $(1990,1993)$ articulation of the heterosexual matrix's mutual constitution through the gender binary is a key influence in the project's challenge to hetero-normativity. A broad concept of GRV is compatible with feminist approaches that problematize all inequalities and attend to power differentials across all forms of social difference (race, ethnicity, class, gender, sexual orientation) and with social theory that emphasises the inter-sectionality of gender with class and ethnicity (Anthias and Yuval-Davis 1993; Brah 1992).

We developed an innovative approach to gender norms, including machismo and hetero-sexism, by drawing on two separate strands of activism and theory, namely, work on VAWG around peer relations, sexual abuse or bullying, and anti-homophobia and trans-recognition. A theoretical question for our study was whether it is possible to broaden the focus without undermining an effective educational intervention on VAWG. As an approach, we might favour 'post-identity' frameworks to ensure that essentialisms are not re-inscribed or binaries assumed or the relations between them sustained. So, focusing on these two separate strands, we hoped that we might develop an approach to deal with machismo and hetero-sexism as gender norms. To what extent we were successful remains questionable, as these notions remain, on occasion, in conflict.

The project was designed to allow four national, or what we called local, actions around developing education or training for professionals regarding GRV with children and young people. Our overarching approach and aims were the same, but we allowed for local, contextual differences in method and in specific definition of what constituted an appropriate pilot structure at this historic juncture. This can be seen in Table 1 below setting out the four local orientations and actions.

Table 1. The four local actions in the UK, Ireland, Italy and Spain *.

\begin{tabular}{|c|c|c|}
\hline Local Actions & The Training Teams & The Theoretical Orientation \\
\hline $\begin{array}{l}\text { UK (Brunel University, London with } \\
\text { UCL IOE) }\end{array}$ & $\begin{array}{l}\text { University researchers with two community } \\
\text { or trainer teams: AYP and ROW }\end{array}$ & $\begin{array}{l}\text { GRV: Interpersonal violence, gender norms, } \\
\text { peer abuse and risk: safeguarding }\end{array}$ \\
\hline Italy (University of Turin) & $\begin{array}{l}\text { University researcher with two local groups: } \\
\text { Maurice (LGBTQi) and Demetra (VAWG) }\end{array}$ & $\begin{array}{l}\text { GRV: health and victim support aspects of } \\
\text { VAWGF and homophobia or abusive forms of } \\
\text { LGBT }\end{array}$ \\
\hline $\begin{array}{l}\text { Spain (University Rovira i Virgili, } \\
\text { Tarragona, Catalonia) }\end{array}$ & $\begin{array}{l}\text { University feminist academic's pedagogies } \\
\text { with local feminist community groups: } \\
\text { Candela (sexualities) and Tamaia (VAWG } \\
\text { recovery) }\end{array}$ & $\begin{array}{l}\text { GRV: Heteronormativity, 'gender violences' } \\
\text { and inclusive environment; personal } \\
\text { reflections }\end{array}$ \\
\hline
\end{tabular}

* Taken from Table 5.1 in Chapter 5 of David (2016a, p. 128).

The approach that each local action adopted illustrated the differences in the precise terms preferred as can be seen from the table above. As the Irish team explained (Alldred and David 2015, p. 16), their preference was for the term GBV and although the other local actions adopted the term GRV, in practice each action problematized homophobia as well as VAWG. Furthermore, employing the same term in English might not mean that the situated action in local contexts and languages have precisely the same definitions and meanings. There are limitations to inter-country comparative studies, and caution must be exercised over comparative conclusions. 
A key issue with this study was its inception from a UK perspective and articulation in English, which meant that the specific terms used may not have been as relevant for the other countries and the comfortable translation of the plural 'violencias' into English eludes us. Indeed, the Spanish team's preference for the plural may distinguish this intervention from other local approaches that use the singular in Spanish. Nevertheless, the plural may make us heed the different forms and responses to GRV.

Overall, we aimed to develop either training or a particular pedagogy, for professionals to work with children and young people at better understanding gender norms and GRV and challenging these norms and practices. As a result of these four separate but intertwined projects, about 450 practitioners have received training and certification for attendance across the four countries. These trainees have received a resource to share their learning with their colleagues and information leaflets are now available in six countries.

In brief, the Irish action developed specialist training for a particular professional group, youth and community workers, through a university education programme, and made a broad intervention by training practitioners already 'in the field'. This team probably produced the most sustainable action because new training is integrated into initial practitioner education at university; it is an impressive legacy.

The UK training had intended to do this but initial teacher education managers did not accept the offer of free training, even though the same staff had previously delivered smaller elements of it in-house and without certification. Accreditation was difficult to obtain in the time period in the UK but an influential National Union of Teachers (NUT) endorsement was valuable. The UK training was a model of evolving training over successful cohorts and identified lessons about organizational issues that would be important to heed in future.

The Italian action made the biggest intervention among health-sector staff and succeeded in obtaining an external accreditation, which helped attract medical personnel to the training. It also enabled many educational professionals to enhance their understanding, given that studies of gender norms are already included in schools in Italy.

The Spanish action, like the Irish, sought personal change and reflexivity about trainees' social positionality and educational experiences. It perhaps had the strongest claim to measurement of learning or personal impact of the training, having trainer evaluations of learning, trainee self-reporting, observation and an indicator of learning from the online assessments completed after training.

The Spanish and the UK teams also have information about interventions the trainees planned to make in their workplaces that were usually broadly educational or social pedagogy. The overriding importance of avoiding judgmental attitudes creeping into some training, by emphasising the pedagogy of personal reflexivity, was a challenge. The core approach was one that locates the heterosexist, sexist, racist environment as the problem and understands us all (trainers, trainees and researchers) as produced through our social and specific environments.

\section{Learning from the European Project about GRV:}

Overall, our own learning about how to develop training rather than education, despite using traditional educational contexts, has given new insights about the difficulties of achieving a good balance between 'hope' and 'despair' during training regarding violence or abuse, especially when a key objective is to increase awareness of these. In particular, we have learnt about the importance of locating GRV in gender equality and the potential to develop training around GRV or GBV, but we perceive the need for theoretical coherence within a training programme. We have also recognized the value of enabling reflection on workplace dynamics and staff experiences, as well as clients' experiences of violence and/or inequality and overall personal and professional development. And we have understood the value of questioning what is identified as violence and what goes unproblematized—both in young people's experiences and in workplace or professional dynamics. 
Overall, the four different actions led us to acknowledge that there is a real and substantive interest and need to address issues related to gender, identity and equality. For example, we were alerted to how pervasive and 'normal' GBV is in Ireland today. Similarly, the Italian action noted that LGBTQi community-related themes continue to be the most ignored. It was important to have the participants explore the cultural roots of violence, and the violence built into the language, even before behaviour, a Foucauldian approach.

In Spain, many participants felt that they had learnt a lot on the course, especially in relation to LGBTQi GRV and in their confidence about interventions. They were also very satisfied with the exercises undertaken and the resources provided, so we imagine that they have been empowered in the process and gained greater awareness of GRV. However, as Colas Bravo and Cortes (2006) have argued, awareness does not automatically produce appropriate actions. Critical awareness may be a prerequisite, in order to comprehend a situation and transform it. We have tried to create opportunities for participants to gain critical distance from their experiences and then to analyze them, coherent with feminist pedagogy.

The UK analysis demonstrates that the training outcomes of the UK programme were met from the point of view of the participants. They felt that they had gained new knowledge, understanding and skills to tackle the themes of GRV and the legal aspect was the most useful for them. Additionally, the seeds were planted for the participants to make initial interventions to tackle GRV with and among the young people they work with, and within their organizations (David 2016a, p. 154). However, we do not know whether the new knowledge and understanding of GRV as an effect of power inequalities has been embedded as a praxis among our participants.

Thus, while the GAP-work project had a complex structure, it has enabled us, as activist feminist researchers, to study how to develop education to facilitate greater understanding of GRV and VAWG amongst and by children and young people. Given that we were with researchers in four very different socio-political and cultural settings, and yet broadly sharing a theoretical perspective on gender inequalities and GRV, we were made crucially aware of the immense need to problematize everyday social norms and to raise awareness of 'gender violences' and the 'violence of gender'.

Centring a multinational project in one country or language sets up dynamics within the group and also conceptually and politically. Research and professional practice needs to be in dialogue with activists and those focused on social justice goals, in order not to limit aspirations for change.

Comprehensive legislation on GRV, that also recognizes the specificity of young people and adopts an intersectional approach, is urgently needed to support situated and effective interventions against GRV. Legislation and social policies are a hugely important element and it is important for youth and educational practitioners to be informed about the law (through so-called 'governance feminism'). This can empower them to adopt a bold stance because they are confident about legal boundaries. Intervening to tackle GRV and the values that sustain it is a broad aim that needs not only to mobilize professionals in everyday contact with children and young people, but to create widespread and profound socio-cultural and political change. There may also be a specific need for the training of men by male professionals to deal with their own feelings (Daniels 2012).

The GAP-work project examined what can be done around training and best practice in four EU countries, demonstrating it is possible to develop innovative training that has an impact on participants. Yet this can only be the first step in a much longer process of getting countries, local areas, organizations and communities working with children and young people to tackle the unacceptably high levels of GRV. This is to raise personal awareness of the embeddedness of gender inequality in our own everyday practices, including how these are reinforced through our interactions with others and in the practices of politics.

Understanding GRV as a continuum as originally developed by the feminist Kelly (1988) is helpful. We need to develop an understanding of how discursive, affective and material structures reinforce gender inequality, in turn driving GRV. The theoretical frameworks of post-structuralism and intersectionality are most productive for understanding societal structures and how everyday 
practices are shaped by and, in turn, reproduce these, while at the same time emphasizing there is always the potential to unsettle these structures, especially through sensitive education. Nevertheless, there remain contradictory foci on feminist questioning of gender norms and homophobia or gender dysphoria. This has only emerged as a major socio-political and educational issue since the conclusion of this project.

\section{Femifesta: The Future of Education and Feminism}

Drawing on various feminist activist research projects, in A Feminist Manifesto for Education, I developed a manifesto with a focus on feminist education (David 2016a, pp. 159-80). I argued that, despite 'gender mainstreaming' and 'global feminism', gender equality cannot have been achieved, if VAWG and GRV remain unsolved questions. What kind of equality have we achieved if women and girls, along with young boys, remain subject to sexual abuse and harassment, bullying, rape and overall violence?

Thus, there remains an important question about what strategies to pursue to achieve freedom and liberation from the constraints of gender binaries and the links with dealing with homophobia for children and young people. I also considered what we have learnt from our struggles to build upon our learning and particular feminist pedagogies, despite contestation. New waves of feminism, in the twenty-first century, are building upon the heritage from previous waves of feminism, and the knowledge and wisdom they developed. Post-structural and third or fourth wave feminists, including governance and carceral feminists, have developed exciting new strategies for formal and informal learning, and new pedagogies that might better counter neoliberalism and its reincorporation of neo-patriarchy in forms of individualism (Renold et al. 2015).

Building upon feminist gains in wisdom and insights, I re-envisioned the idea of 'demands' of the WLM of the 1970s, or 'from cradle to grave' to put it back in terms of the agenda of the British welfare state circa 70 years ago. Given the huge socio-economic and political transformations, is it possible to think about what elements of these seven demands could usefully be re-invoked as part of a feminist manifesto today? In particular, how can we relate those 'demands on the social democratic state' to demands on the reconfigured neoliberal, neo-patriarchal state and dealing with the seventh demand in particular: elimination of VAWG through education, including political education?

This neoliberal state, as we have seen, is both much less interventionist fifty years on, and also far more committed to rampant individualism and market competition (Campbell 2013; Fraser 2013). It has found ingenious new ways of infiltrating across new media and informal education, especially in and through sexualisation. Can our demands be adapted to new forms of democratization for new generations and waves of not only feminists but also children and young people? What precisely would that entail for forms of education? How can we think about dignity and respect for future generations as well as equality and fairness, to ensure that we are all safeguarded from the risks of GRV (Kelly 2005)?

This approach must include both a new philosophy of education about gender, gender identities and the recently identified important new question of gender dysphoria to deal with emergent new gender identities, especially for young people in their teenage years. What is the training or education of professionals to go with this and ensure sensitivity to these emergent gender issues, without re-inscribing them in traditional gender binaries? This is the big question of the second half of the second decade of the twenty-first century. Revisiting the (Gender Recognition Act 2004) in the UK has become an urgent question, as it is an example of 'gender mainstreaming' to such an extent that gender binaries have become vital for dealing with gender dysphoria amongst young people.

It must go beyond the simple implementation of sex and relationship education (SRE) and personal, social and health education (PSHE) in all forms of compulsory education, tailored to the needs of particular ages of students or pupils. In the UK, this remains an important policy to be resolved. The UK government has refused to ensure that even a minimal policy should be compulsory for all schools, and yet this is vital as a form of personal and political education. Benn (2013) tried 
nobly to develop an agenda for the education of girls, through not only schools but also interpersonal relationships. Indeed, the question of the training of the professionals to implement this policy of gender sensitive education has yet to be solved. Our GAP-work project pointed to important pedagogical lessons from Ireland for youth professionals, Italy for medical and para-medical or care workers, and Spain especially for sensitive feminist pedagogies that also consider homophobia. Taking the work into lifelong learning and post-secondary education is an important part of the learning from this rich study. Together these constitute not only legal changes but also political education.

The focus on education contrasts with Tutchell and Edmonds' recommendations. They are specifically interested in how to develop or reclaim (socialist) feminism as "that deep belief in the rights and entitlement of women, which we call feminism ..." (Tutchell and Edmonds 2018, p. 9). They remain second wave feminists and present feminist demands that continue to focus squarely on politics and legislation through the British state. This is their great 'third leap forward' whereby they argue for a more gender-balanced Parliament and Government whilst only considering the first four demands of the 1970s, which have been largely implemented, or are under discussion in political circles today.

However, they do name 'everyday sexism' (Bates 2014) and how this has been identified and named as sexual abuse and harassment. They also review Banyard (2016) consideration of 'the pimp state' and how prostitution remains the preserve of individuals rather than regulated by the state, so that poor women do not have to resort to these dangerous practices that lead to abuse and harassment as a way of making ends meet. They go beyond these, however, in also discussing how to make socio-cultural change, and making the world a happier place. There is no question that this is a vital and crucial collective goal, especially if taken together with addressing VAWG and GRV.

Hickey-Moody (2016) has a post-structural or post-human feminist approach to these questions. She mobilises

“a manifesto/manifesta/femifesta as a genre of feminist scholarship... The manifesta, or femifesta ... has provided a model for advancing a call to action in scholarship, but also in popular culture".

Hickey Moody argues that the manifesto has been mobilized in various forms and contexts as a 'feminist modality'. She goes on to argue that affective pedagogy is a framework for thinking through the pedagogical shift in perception. It is important that pedagogies are taken more seriously as ways of transforming perceptions than changing legislation.

Finally, in conclusion, the notion of a manifesto or femifesta is rich in suggestions and sensitivities for a feminist pedagogy, or an approach not only to formal education but also lifelong learning (David 2017). In undertaking the GAP-work project the learning amongst the team was also rich and important, building upon previous feminist knowledge and learning. It led to our understanding of the learning that our participants across the four countries of the EU made and how gender mainstreaming has both very positive and also very negative effects. As I have argued (David 2016b), similarly, "feminism is everywhere and yet nowhere (is it) influential or powerful". To make the educational and socio-legal changes necessary for a transformed and happier society, a collective commitment to a femifesta or manifesto is a vital first step.

Acknowledgments: Dr Pam Alldred of Brunel University, London was the coordinator and recipient of a grant from the European Union's Daphne-III Programme, 'GAP Work: Improving gender-related violence intervention and referral through youth practitioner training' (JUST/2012/DAP/AG/3176 (2013-2015). I was involved as a co-investigator. I am very grateful to Dr Alldred and Dr Barbara Biglia of Universitat Rovira I Virgili, Tarragona, Spain for their collegiality and friendship on this project.

Conflicts of Interest: The author declares no conflict of interest. 


\section{References}

Alldred, Pam, and Barbara Biglia. 2015. Gender-related violence and young people: An overview of Italian, Irish, UK and EU legislation. Children and Society 29: 662-75. [CrossRef]

Alldred, Pam, and Miriam E. David. 2007. Get Real about Sex: The Politics and Practice of Sex Education. London: McGraw Hill/Open University Press.

Alldred, Pam, and Miriam E. David, eds. 2015. GAP Work Project Report: Training for Youth Practitioners on Tackling Gender-Related Violence. London: Brunel University. Available online: http://sites.brunel.ac.uk/gap/ resources/reports (accessed on 15 June 2016).

Anthias, Floya, and Nira Yuval-Davis. 1993. Racialised Boundaries: Race, Nation, Gender, Colour, Class and the Anti-Racist Struggle. London: Routledge.

Arribas, Gracia Vara, and Laura Carrasco. 2003. Gender Equality and the EU: An assessment of the current issues. Eipascope 1: 22-30.

Banks, Olive. 1986. Becoming a Feminist: The Social Origins of First Wave Feminism. Brighton: Wheatsheaf Books.

Banyard, Kat. 2016. The Pimp State: Sex, Money and the Future of Equality. London: Faber and Faber.

Bates, Laura. 2014. Everyday Sexism. London: Simon and Shuster.

Benn, Melissa. 2013. What Should We Tell Our Daughters? The Pleasures and Pressures of Growing up Female. London: John Murray.

Biglia, Barbara, and Maria Olivella-Quintana. 2014. Evolution and involution in the sexual and reproductive health services in Catalonia (Spain). Women's Studies International Forum 47: 309-16. [CrossRef]

Biglia, Barbara, Maria Olivella-Quintana, and Sofia Cagliero, eds. 2015. Gender-Related Violence Legislation in Europe. Tarragona: Universitat Rovira I Virgili.

Brah, Avtar. 1992. The Scent of Memory: Strangers, our own and others. Feminist Review 100: 6-26. [CrossRef]

Butler, Judith. 1990. Gender Trouble: Feminism and the Subversion of Identity. New York and London: Routledge.

Butler, Judith. 1993. Bodies That Matter: On the Discursive Limits of 'Sex'. New York and London: Routledge.

Campbell, Beatrix. 2013. End of Equality: The Only Way is Women's Liberation. London: Seagull Books.

Colas Bravo, María Pilar, and Rocío Jimenez Cortes. 2006. Tipos de consciencia de genero del profesorado en los contextos escolares. Revista de Educacion 340: 415-44.

Daniels, Luke. 2012. Pulling the Punches: Defeating Domestic Violence. London: Bogle-L'Ouverture Press.

David, Miriam E. 2003. Personal and Political: Feminisms, Sociology and Family Lives. Stoke-on-Trent: Trentham Books.

David, Miriam E. 2014. Feminism, Gender and Universities: Politics, Passion and Pedagogies. London: Ashgate/Taylor and Francis.

David, Miriam E. 2016a. A Feminist Manifesto for Education. Cambridge: Polity Press.

David, Miriam E. 2016b. Reclaiming Feminism: Challenging Everyday Misogyny. Bristol: Policy Press.

David, Miriam E. 2017. Femifesta? Reflections on writing a feminist memoir and a feminist manifesto. Gender and Education 29: 525-36. [CrossRef]

Ehrenreich, Barbara, and Deirdre English. 1973. Witches, Midwives and Nurses. New York: The Feminist Press.

Fraser, Nancy. 2013. Fortunes of Feminism: From State-Managed Capitalism to Neoliberal Crisis. London: Routledge.

Gender Recognition Act, 2004. UK. Available online: https://www.legislation.gov.uk/ukpga/2004/7/contents (accessed on 4 June 2018).

Hafner-Burton, Emilie, and Mark A. Pollock. 2000. Mainstreaming gender in the European Union. Journal of European Public Policy 7: 432-56.

Halley, Janet. 2006. Split Decisions: How and Why to Take a Break from Feminism. Princeton: Princeton University Press.

Harman, Harriet. 2017. A Woman's Work. London: Allen Lane Penguin Random House.

Hewitt, Nancy, ed. 2010. No Permanent Waves: Recasting the Histories of US Feminism. New Brunswick: Rutgers University Press.

Hickey-Moody, Anna. 2016. A Femifesta for Posthuman Art Education: Visions and Becomings. In Posthuman Research Practices in Education. Edited by Carol Ann Taylor and Christina Hughes. London: Palgrave Macmillan.

Kelly, Liz. 1988. Surviving Sexual Violence (Feminist Perspectives). Cambridge: Polity Press. 
Kelly, Liz. 2005. Inside outsiders: Mainstreaming gender violence into human rights discourse and practice. International Feminist Journal of Politics 7: 471-95. [CrossRef]

Millns, Susan, and Charlotte Skeet. 2013. Gender Equality and legal mobilization in the United Kingdom: Using rights for lobbying, litigation, defence and attack. Canadian Journal of Law and Society 28: 169-88. [CrossRef]

Montoya, Celeste. 2009. International initiative and domestic reforms: European Union efforts to combat violence against women. Politics and Gender 5: 325-48. [CrossRef]

Renold, Emma, Jessica Ringrose, and R. Danielle Egan, eds. 2015. Children, Sexuality and Sexualization. Basingstoke: Palgrave Macmillan.

Tutchell, Eva, and John Edmonds. 2018. The Stalled Revolution: Is Equality for Women an Impossible Dream? Bingley: Emerald Publishing.

Walby, Sylvia. 1986. Patriarchy at Work: Patriarchal and Capitalist Relations in Employment. Cambridge: Polity Press. Walby, Sylvia. 2002. Feminism in a global era. Economy and Society 31: 533-57. [CrossRef]

Walby, Sylvia. 2011. The Future of Feminism. Cambridge: Polity Press.

White, Penny. 2015. A thank you note to 'carceral' /'sex-negative' feminists. Feminist Current, October 5.

Wollstonecraft, Mary. 1972. A Vindication of the Rights of Women. Buffalo: Prometheus Books. Originally published in 1792 in the UK.

(C) 2018 by the author. Licensee MDPI, Basel, Switzerland. This article is an open access article distributed under the terms and conditions of the Creative Commons Attribution (CC BY) license (http:/ / creativecommons.org/licenses/by/4.0/). 